\title{
Report of the Panel on \\ Bacteriology and Immunology
}

Chairman: J. H. Hanks (USA); Secretary:

Members: J. O. Almcida (Brazil); N. Souza Campos (Brazil); R. S. Guinto (Philippines); S. W. A. Kuper (UK); E. Montestruc (France); A. Rotberg (Brazil); Candido Silva (Brazil); K. Yanagisawa (Japan); Y. Yoshic (Japan); G. P. Youmans (USA).

The report from DR. J. H. HANKS not being available, DR. S. W. A. KUPER, a member of the Panel, has contributed the following appraisement.

A full written report was not available at the time the Chairman, DR. HANKs, made his address but he read an account of the proceedings of the three Sub-Committecs, namely, Bacteriology, Immunology and Serology. In the findings of each Sub-Committee, the comments were roughly divided into a review of existing knowledge, and recommendations for standards and for future research. The Chairman stressed the difficulties which exist when there is inadequate International liaison. He appealed for some permanent body to be set up to provide this liaison and to attempt standardisation of such substances as lepromin.

(a) Bacteriology. 'The cultural requirements of Mycobacterium leprae were briefly reviewed and their complexity discussed. Scales were suggested for recording the number of bacilli seen in smears and a further plea was made for standardisation to be effected by constant international co-operation instead of spasmodic five-year attempts. 
(b) Serology. The Chairman stressed the different nature of skin reactivity and antibody formation in mycobacterial discase. It is clearly not surprising that antibody formation (a serological phenomenon) and skin reactivity seldom coincide. Research into scrological investigations is in hand in the Americas but some patients with lepromatous leprosy have circulating antibodies and antigen-antibody complexes. 'The latter have been shown to produce periodic depletions of circulating complement. Consideration is being given to the question of identifying bacteriologically positive individuals before they develop lesions.

(c) Immunology. The importance of genetic factors is being realised. Populations appear to consist of three groups of people which are evident even in infancy (a) average responders, which includes the bulk of the population; (b) slow and modest responders, who, if they become infected, get non-lepromatous discase; (c) poor responders; in the event of infection these people develop 'borderline' leprosy which may continue to dimorphous and finally lepromatous discasc.

\section{ACIQUIRED RESISTANCE}

It has been shown that this is not due to artibody production. It is suggested that acquired resistance may be duc to an improved capacity of mesenchyme to digest the cell walls and hydrolyse the proteins of the cells. ('The sensitivity of patients to freed toxin from the cells may vary from case to case.) It may be that immunised people are able to break down cells more rapidly than other persons; the cell walls are very toxic. 'This ability of patients to digest bacilli may well be a more important factor in mycobacterial disease than the patient's capacity to produce antibodies.

I M MU NIS A TION

It should be our aim to immunise the small sector of the population that is poorly equipped genetically to deal with $M$. leprae. The average responders, it is contended, do not need help and at this juncture we have no mechanism for helping the poor responders. The intermediate group, however, may perhaps be assisted by BCG vaccination, if this agent can be shown to have any immunising power at all in leprosy. Cutaneous reactivity to antibacterial antigens rises with age and if this group can be helped, it must be done very early in life.

\section{STANI)ARIISA TION}

liermandez: $\Lambda$ s stated in Madrid and 'Tokyo.

Mitsuda: It is desirable to read reactions at weekly intervals for six weeks or even eight to ten weeks if the full prognostic value is to be obtained. It is suggested that the Wade phenomenon may be due to children not having had a previous challenge by similar antigens, so that their reactivity develops slowly. The Castro phenomenon, an accelerated reaction, may be due to previous experience of the antigens. 
Reading of Mitsuda: If the antigen contains 160 million bacilli per $\mathrm{ml}$. (this concentration is suggested by the similar results obtained in the Japanese and Philippine lepromin experiments) the following criteria should be used:

$\begin{array}{lll}0 \quad \mathrm{~mm} \text {. induration } & =0 \quad \text { (Negative) } \\ 5 \mathrm{~mm} \text {. induration } & \pm \quad \text { (I)oubtful) } \\ 5-9 \mathrm{~mm} \text {. induration (inclusive) } & =+\quad \text { (Positive) } \\ \text { I } \mathrm{mm} \text {. induration or more } & =++ \text { (Strongly positive) }\end{array}$

It was suggested that trials should be carried out with lepromin diluted eight-fold. Some evidence was produced to show that this would climinate 'non-specific' reactions and greatly extend world supplies of lepromin.

'The Sub-Committec of the World Health Organisation will attempt the standardisation of lepromin at centres set up for the purpose.

In the discussion that followed the Chairman's report, it became clear that some members had misunderstood the guarded remarks about BCG vaccination and thought the Chairman had given the Sub-Committec's approval of its use. 'I'his was clarified and it was pointed out that all the comments relating to the use of BCG should be cautiously regarded, because the Sub-Committec had not found any real proof of the efficacy of BCG vaccination in the prophylaxis of leprosy.

PERSONAL REMARKS

I think the concept of cell breakdown causing local allergy, and the completely different phenomenon of antibody formation are useful. As far as my own personal knowledge is concerned, many of the theses put forward seem speculative but they do provide a reasonable approach to the subject. I do not like the form in which we have categorically stated the details of these mechanisms, as though they were widely accepted and experimentally proved.

The gravest criticism I feel, concerns the form in which BCG vaccination has been advocated. I know most members of the Panel shared my uncasiness. Though the efficacy of BCG is not explicitly claimed, the form of question and answer tacitly assumes its efficacy. 'To me it secms that asking the question 'W'ith what to immunise?' is exactly analogous to the question 'Have you stopped beating your wife? Answer yes or no'.

To sum up, I think Hanks's suggestion of attempted standardisation of lepromin is an excellent one. On the other hand, I think the advocacy of BCG vaccination has no proved basis, and leprosy workers should be quite clear if they use BCG that they are using it to produce some immunity to tuberculosis (even this is small enough in all conscience). There is some evidence of 'overlapping' of allergic reaction to lepromin and tuberculin but in terms of Hanks's own recommendations these local allergic reactions must not be confused with the development of antibodies. Much more work would be necessary (and I think it will have to be epidemiological) to ascertain whether $B C G$ has any prophylactic effect against leprosy. Personally I know of no evidence that it has and my own opinion is that it has not. 